mortality strongly. Nevertheless, our findings are reassuring to the extent that the possible absolute risk carried by passive smoking is probably small.

This study was supported by a grant from the Netherlands Heart Foundation. Help from the Civil Servants Pension Fund (Heerlen) and from the city of Amsterdam is gratefully acknowledged.

1 Doll R, Gray R, Hafner B, Peto R. Mortality in relation to smoking: 22 years' observation in female British doctors. Br Med F 1980;i:967-71. ${ }^{2}$ Hirayama T. Non-smoking wives of heavy smokers have a higher risk of lung cancer: a study in Japan، $\mathrm{Br}$ Med $\mathcal{F} 1981$;282:183-5.

${ }^{3}$ Correa P, Pickle LW, Fontham E, Lin Y, Haenszel W. Passive smoking and lung cancer. Lancet 1983;ii:595-7.

4 van der Heide RM. Resultaten van een geneeskundig onderzoek van 3091 gezonde mannen en vrouwen (with English summary: Results of a medical examination of 3091 healthy men and women, pp 128-30). Amsterdam: University of Amsterdam, 1959. $\mathrm{PhD}$ thesis.

${ }^{5}$ Vandenbroucke JP, Matroos A, van der Heide-Wessel C, van der Heide RM. Parental survival, an independent predictor of mortality in middleaged persons. Am $\mathcal{F}$ Epidemiol 1984;119:742-50.

(Accepted 29 March 1984)

Department of Epidemiology, Erasmus University, 3000 DR Rotterdam, The Netherlands

J P VANDENBROUCKE, MD, PHD, epidemiologist

Department of Environmental and Tropical Health, Agricultural University, Wageningen

J H H VERHEESEN, student

A DE BRUIN, student

B J MAURITZ, student

Department of Health, City of Amsterdam

C VAN DER HEIDE-WESSEL, MD, retired community physician

Academic Hospital, University of Amsterdam

R M VAN DER HEIDE, MD, PHD, infectious disease physician

Correspondence to: Dr J P Vandenbroucke.

\section{Brucellosis with mesangial IgA nephropathy: successful treatment with doxycycline and rifampicin}

We report on a patient with acute brucellosis and mesangial IgA nephropathy. Clinical and biochemical evidence of the glomerulonephritis disappeared after treatment of the infection but the histological lesion persisted.

\section{Case report}

A 20 year old Saudi Arabian man with a history of fever for 12 weeks, weight loss of about $10 \mathrm{~kg}$, and painless haematuria for three weeks was referred to us for investigation. His fever reached up to $40^{\circ} \mathrm{C}$, and he had macroscopic haematuria and proteinuria, but there were no other abnormalities. Investigations showed haemoglobin $12.7 \mathrm{~g} / \mathrm{dl}$, white blood count $6.5 \times 10^{\circ} / 1$ (48\% neutrophils, $40 \%$ lymphocytes), blood urea $8.2 \mathrm{mmol} / 1$ $(49 \mathrm{mg} / 100 \mathrm{ml})$, serum creatinine $167 \mu \mathrm{mol} / 1(1.9 \mathrm{mg} / 100 \mathrm{ml})$, serum albumin $38 \mathrm{~g} / \mathrm{l}$, serum IgA $8.35 \mathrm{~g} / 1$ (normal $1.5-4.7 \mathrm{~g} / \mathrm{l}$ ). Examination of his urine over 24 hours showed that protein varied from $0.6 \mathrm{~g}$ to $2.8 \mathrm{~g}$, and creatinine clearance averaged $61 \mathrm{ml} / \mathrm{min}$. The following investigations were normal: liver function tests, estimations of blood lipids, blood films for malarial parasites, urine cultures, virological screen, tests for antinuclear antibodies, complement profile, serum IgG and IgM estimations, chest radiograph, and intravenous urogram. Cystoscopy was normal. A needle renal biopsy showed a focal and segmental proliferative glomerulonephritis with widespread mesangial changes in all 15 glomeruli; interstitial inflammation was minimal. Immunofluorescence microscopy showed heavy mesangial deposits of IgA without deposition of IgG or IgM. Mesangial IgA nephropathy was diagnosed.

After 10 days a fastidious Gram negative coccobacillus was isolated from blood cultures taken on admission and identified as Brucella melitensis type 3. Serological tests for brucellosis showed complement fixation titre $>1 / 1256$, IgA and IgM (enzyme linked immunosorbent antibody test) titres $>1 / 640$; agglutination titre $>1 / 1280$. The organism was resistant to sulphamethoxazole and trimethoprim but sensitive to rifampicin and doxycycline (minimal inhibitory concentration $1 \mathrm{mg} / 1$ and $0.03 \mathrm{mg} / 1$ respectively). A bactericidal synergy was shown between doxycycline and rifampicin. The patient regularly drank milk from camels, goats, and cows.

He was treated with oral doxycycline $200 \mathrm{mg}$ and rifampicin $450 \mathrm{mg}$ daily. The fever abated after five days, and after nine days the serum creatinine had fallen to $88 \mu \mathrm{mol} / 1(0.1 \mathrm{mg} / 100 \mathrm{ml})$ and the blood urea to $4.3 \mathrm{mmol} / 1$ $(25.9 \mathrm{mg} / 100 \mathrm{ml})$.

After three months' treatment he had no symptoms or fever, and had gained $10 \mathrm{~kg}$. Serum creatinine and blood urea values were normal; there was no proteinuria, and creatinine clearance was $111 \mathrm{ml} / \mathrm{min}$. A second renal biopsy showed that the previous mild interstitial inflammation had resolved, but the glomerular mesangial abnormalities persisted and IgA deposits could still be shown.

Two months after the first admission the technician who had subcultured the blood cultures from this patient developed clinical infection with Brucella melitensis type 3. His infection also responded to rifampicin and doxycycline.

\section{Comment}

Interstitial nephritis ${ }^{1}$ and acute exudative glomerulonephritis ${ }^{2} \mathbf{s}$ are recognised renal complications of brucellosis but the association with IgA nephropathy has not previously been recorded. Most accounts of renal disease in this infection were written before immunofluorescence was used in the examination of renal biopsy specimens, without which IgA nephropathy cannot be diagnosed. In our patient the successful treatment of brucellosis was accompanied by the disappearance of haematuria and proteinuria and a return to normal of creatinine clearance and serum IgA concentration. A causal relation between brucellosis and IgA nephropathy is thereby suggested, yet mesangial deposition of IgA persisted.

Brucellosis is usually treated with tetracycline and streptomycin or with co-trimoxazole. The organism isolated from our patient was resistant to co-trimoxazole, while the nephropathy made tetracycline undesirable. Bactericidal synergy was shown between rifampicin and doxycycline. This combination, with the advantage of once daily oral medication, proved successful in the patient and the laboratory technician.

${ }^{1}$ Dunea G, Kark RM, Lannigan R, D'Alessio D, Muehrcke RC. Brucella nephritis. Ann Intern Med 1969;70:783-90.

${ }^{2}$ Call JD, Baggenstoss AH, Merritt WA. Endocarditis due to brucella: report of two cases. Am f Clin Pathol 1955;14:508-18.

${ }^{3}$ Orte L, Teruel JL, Bellas C, et al. Nefropatia brucelosica: descripcion de tres casos. Rev Clin Esp 1979;152:461-4.

(Accepted 9 April 1984)

Departments of Renal Medicine and Microbiology, St Thomas's Hospital, London SE1 7EH

T O NUNAN, MSC, MRCP, senior medical registrar

$S$ J EYKYN, MB, MRCPATH, reader in clinical microbiology

N F JONES, MD, FRCP, consultant physician

Correspondence to: Dr T O Nunan.

\section{AIDS in a patient with Crohn's disease}

Acquired immune deficiency syndrome (AIDS) mainly occurs in specific risk groups. ${ }^{2}$ We have seen a heterosexual man who belonged to none of the risk groups for acquired immune deficiency syndrome (AIDS) but developed a defect of cellular immunity three years before the recognition of the current epidemic increase ${ }^{2}$ and was subsequently found to have Crohn's disease.

\section{Case report}

A white heterosexual native of Lancashire who had never left the country or entertained people at risk presented in 1976 aged 37 with recurrent oesophageal candidiasis. In 1977 he developed lower abdominal pain, weight loss, and diarrhoea. After a barium enema Crohn's disease of the ascending colon was diagnosed at laparotomy and confirmed histologically. He underwent repeated operations for the complications of the condition between 1977 and 1980, during which he had a right hemicolectomy, but less than $30 \mathrm{~cm}$ of terminal ileum were removed. During this period he received seven units of whole blood. He did not receive steroids or immunosuppressant drugs during this period or subsequently. 
In July 1982 he developed fever, cough productive of blood stained mucopurulent sputum, malaise, and weight loss. A chest $x$ ray film showed an abscess in the lingula and associated pulmonary infiltrates. The results of microbiological examinations of the sputum were persistently negative. No improvement was seen despite repeated courses of antibiotics. Bronchoscopy showed no obstruction but friable submucosal plaques. Pneumocytosis was diagnosed histologically and the lung lesion resolved with high dose cotrimoxazole.

In January 1983 he was admitted; he was febrile with encephalopathy and had a generalised rash three weeks after an episode of shingles in the thoracic 5-6 dermatomes. Cerebrospinal fluid protein was $2.29 \mathrm{~g} / 1$ and the fluid contained 294 white cells $\left(0.294 \times 10^{9} / 1\right)$, of which $90 \%$ were lymphocytes. No bacteria or viruses were isolated. This disseminated zoster infection responded to parenteral acyclovir, but recovery was complicated by a recurrence of oesophageal candidiasis. In October 1983 he developed two painful indurated lumps on the chest wall. A biopsy specimen showed a squamous carcinoma, from which he died in November 1983. The primary site was not identified.

A persistent increase in suppressor and decrease in helper peripheral blood $T$ cell numbers was found with the commercially available monoclonal antibodies OK T 3, OK T 4, and OK T 8 (Ortho Diagnostics, Raritan, New Jersey). The total lymphocyte count was $1.72 \times 10^{9} / 1$ (control $1.05-3.05 \times$ $10^{9} / 1$ ), of which $1.12 \times 10^{9} / 1$ (control $0 \cdot 8-1 \cdot 63 \times 10^{9} / 1$ ) were OK T 3 positive ( $\mathrm{T}$ cells), $1.07 \times 10^{9} / 1$ (control $0 \cdot 26-0.82 \times 10^{9} / 1$ ) OK T 8 positive (suppressor), and $0.23 \times 10^{9} / 1$ (control $0.54-1 \cdot 11 \times 10^{9} / 1$ ) OK T 4 positive (helper) The helper suppressor ratio was $0 \cdot 2$ (normal 1.0-3.0). Total serum IgG, IgA, and $\operatorname{IgM}$ concentrations were normal. The patient had negative specific tests for syphillis, a negative tine test and was $\mathrm{HbsAg}$ negative. Screening for autoantibodies including rheumatoid factor, antinuclear factors, and DNA antibodies gave negative results.

\section{Comment}

Our patient suffered from a series of unusual opportunistic infections and malignancy accompanied by the pattern of immune paresis described in the acquired immune deficiency syndrome (AIDS). ${ }^{12}$ $\mathrm{He}$ did not fall into one of the recognised risk groups and he had no known contact with anyone from such a group. He acquired the immune paresis three years before the first description of AIDS in the USA. Possibly he represents one of the presumably rare and as yet unrecognised individuals from whom the current epidemic in at risk populations arose. Alternatively, his acquired immune deficiency may have resulted from Crohn's disease. His first infection predated clinical evidence of Crohn's by more than a year. Alterations in T lymphocyte populations in the highly specialised gut mucosal immune system occur in Crohn's disease ${ }^{3}$ and anergy to skin test antigen has been shown. Studies of circulating $\mathrm{T}$ lymphocyte populations have yielded conflicting results but a recent study using monoclonal antibody techniques found no change in helper or suppressor $\mathrm{T}$ cell populations, regardless of disease activity, site, extent, or mode of treatment. Finally, transfusion of blood and its products is a possible mode of transmission of acquired immune deficiency syndrome. ${ }^{5} \mathrm{He}$ received multiple transfusions only after Crohn's disease presented one year after the first infective episode. We believe that acquired immune deficiency syndrome was the primary event in our patient.

We thank Dr S A Cairns for his advice and encouragement during the preparation of this paper and Dr N Williamson and Dr P Johns and their staff at the subregional immunology laboratories at Preston Infirmary for their expert technical help.

1 Center for Disease Control. Acquired immunodeficiency syndrome (AIDS). Update-United States. MMWR 1983;32:309-11.

2 Waterson AP. Acquired immunodeficiency syndrome. $\mathrm{Br} \mathrm{Med} \mathcal{F} 1983$; $286: 743-6$.

${ }^{3}$ Fiocchi C, Youngman KR, Farmer RG. Immunoregulatory function of human intestinal mucosa lymphoid cells: evidence for enhanced suppressor cell activity in inflammatory bowel disease. Gut 1983;24: 692-701.

4 Selby WS, Jewell DP. T lymphocyte subsets in inflammatory bowel disease: peripheral blood. Gut 1983;24:99-105.

5 Jett JR, Kuitsky JN, Katzmann JA, Homburger HA. Acquired immune deficiency syndrome associated with blood-product transfusions. Ann Intern Med 1983;99:621-4.

(Accepted 28 February 1984)

Department of Medicine, Royal Preston Hospital, Preston

J M DHAR, MD, MRCP, registrar

N D PIDGEON, MB, registrar

A L BURTON, MB, MRCP, consultant physician

Correspondence to: Registrar in Medicine, East Birmingham Hospital, Bordesley Green East, Birmingham B9 5ST.

\section{Do chillies influence healing of duodenal ulcer?}

Chillies are generally believed to be harmful to patients with duodenal ulcer. Consequently, these patients are advised to take a relatively bland diet containing little or no spices and chillies. This view is perhaps based on experimental findings that red chilli powder damages the gastric mucosa. Intragastric instillation of red chilli powder in human volunteers caused a considerable increase in the deoxyribonucleic acid content of gastric aspirate, suggesting exfoliation of the surface epithelial cells. ${ }^{1}$ This effect has been reproduced with capsaicin, the active principle of chillies. ${ }^{2}$ The results concerning acid production are conflicting: one study showed no effect ${ }^{3}$ while another found considerably increased acid concentrations in both controls and patients with duodenal ulcer after intragastric infusion of red chilli powder. ${ }^{4}$ The effect of chillies on the healing rate of duodenal ulcer has not been determined, how trolled trial on patients in hospital.

\section{Patients, methods, and results}

Fifty consecutive patients with endoscopically proved duodenal ulcer were studied. None of the patients had been on recent specific antiulcer treatment and none had ulcer related complications such as haemorrhage or perforation. None had had gastric surgery or suffered from any systemic illness. Patients were admitted to the hospital and were randomly allocated to one of the two groups. Group 1 consumed a normal hospital diet (without any chillies) and took liquid antacid (Aludrox $\mathrm{MH}$ ) containing aluminium hydroxide $61 \mathrm{~g} / 1$ and magnesium hydroxide $20 \mathrm{~g} / 1$ (neutralising capacity $2 \cdot 3$ $\mathrm{mol} / \mathrm{l}$ ) in a dose of $15 \mathrm{ml}$ one hour and three hours after each meal, six times a day. Group 2 in addition to the above treatment received $3 \mathrm{~g}$ red chilli powder ( $1 \mathrm{~g}$ with each meal) a day. Treatment was continued for four weeks. The patients were assessed clinically each week, and symptoms were recorded on a form. Patients underwent endoscopy after four weeks and the findings were categorised as: $(a)$ healing of duodenal ulcer with or without residual duodenitis and $(b)$ non-healing of ulcer (irrespective of its size). The examiner doing the endoscopy was unaware of the treatment received by the patient.

The results are shown in the table. Weekly comparison of symptomatic relief showed no real difference between the two groups throughout the study period. After four weeks of treatment ulcer healing was identical $(80 \%)$ in both groups. Patients receiving chillies showed no gastric mucosal abnormalities such as hyperaemia or erosions at endoscopy. Two out of 25 patients in group 2 had mild intolerance to chillies and two from group 1 and four from group 2 developed mild constipation, but none had to stop treatment.

Clinical details and endoscopic healing rate in the two groups of patients with duodenal ulcer

\begin{tabular}{lcc}
\hline & Group 1 & Group 2 \\
\hline $\begin{array}{l}\text { No of patients } \\
\text { Age (yr) }\end{array}$ & 25 & 25 \\
Mean (SD) & $36 \cdot 8(11 \cdot 1)$ & $32 \cdot 6(12 \cdot 8)$ \\
Median & 35.1 & 28 \\
Men:women & $24: 1$ & $24: 1$ \\
Duration of symptoms (yr) & $4 \cdot 92(4 \cdot 58)$ & $5 \cdot 28(4 \cdot 9)$ \\
Mean (SD) & 3 & 4 \\
Median & $1-15$ & $1-15$ \\
Range & 19 & 17 \\
No of smokers & 15 & 13 \\
No of patients with symptomatic relief in: & 18 & 20 \\
Week 1 & 20 & 21 \\
Week 2 & 23 & 22 \\
Week 3 & 20 & 20 \\
Week 4 & & \\
No with endoscopic healing & & \\
\hline
\end{tabular}

\section{Comment}

In the present study $3 \mathrm{~g}$ of red chilli powder was given daily, which is the usual amount consumed in India. ${ }^{3}$ Antacid was administered in a dose of $15 \mathrm{ml}$ six times a day since we find this to be the optimal quantity required for healing of duodenal ulcer. ${ }^{5}$ In previous studies red chillies have damaged the gastric mucosa. ${ }^{12}$ In those experiments, however, the chilli powder or capsaicin (its active principle) was instilled directly into a fasting stomach by means of a tube. ${ }^{12}$ Moreover, the evidence of damage was transitory and was not observed once the infusion was stopped. ${ }^{2}$ In our study red chillies were found not to influence the healing of duodenal ulcer. Moreover, we did not observe any gastric mucosal damage in the form of hyperaemia or erosions. In view of these findings we recommend that patients with duodenal ulcer may consume a normal diet and that bland food is unlikely to serve any useful purpose. 